\title{
Potential risky exotic fish species, their ecological impacts and potential reasons for invasion in Korean aquatic ecosystems
}

\author{
Usman Atique (iD and Kwang-Guk An*(iD) \\ Department of Bioscience and Biotechnology, Chungnam National University, Daejeon 34134, Republic of Korea
}

ARTICLE INFO

Received October 4, 2021

Accepted January 16, 2022

Published on February 16, 2022

*Corresponding author

Kwang-Guk An

E-mail kgan@cnu.ac.kr

\begin{abstract}
Background: Due to the rapidly changing climatic conditions, South Korea faces the grand challenge of exotic species. With the increasing human movement, the influx of alien species to novel regions is prevalent across the globe. The latest research suggests that it is easy to prevent the introduction and establishment of alien species rather than controlling their spread and eradication. Like other countries, the Korean Ministry of Environment released a list (in 2018) of 45 potential risky exotic fish species considered likely to be invasive candidate fish species if they ever succeed in entering the Korean aquatic ecosystems.

Results: The investigation into the invasion suitability traits showed that potential risky fish species could utilize those features in becoming invasive once they arrive in the Korean aquatic ecosystems. If the novel species establish viable populations, they are likely to incur higher economic costs, damage the native aquatic fauna and flora, and jeopardize the already perilled species. Furthermore, they can damage the installed infrastructure, decline overall abundance and biodiversity, and disturb the ecosystem services. Here we reviewed the list of fish species concerning their family, native origin, preferred aquatic biomes, main food items, current status in Korea, and potential threats to humans and the ecosystems. Data shows that most species are either already designated as invasive in the neighboring counties, including Japan, Vietnam, Thailand, and China, or originate from these countries. Such species have a higher climate match with the Korean territories. Conclusions: Therefore, it is exceptionally essential to study their most critical features and take regulatory measures to restrict their entry. The incoming fish species must be screened before letting them in the country in the future. The regulatory authorities must highlight the threatening traits of such species and strictly monitor their entrance. Detailed research is required to explore the other species, especially targeting the neighboring countries fish biodiversity, having demonstrated invasive features and matching the Korean climate.
\end{abstract}

Keywords: Korea, exotic species, risky fish, fish control, spread, ecological impacts

\section{Introduction}

Invasive alien species (IAS), also known as non-native species (NNS), are a persistent and devastating threat to biodiversity, ecosystems, and services (Cuthbert et al., 2021; Pyšek et al. 2020). Scientists are continuously warning about the increasing global invasions, simultaneous threats to the ecosystems, and damages leading to huge socioeconomic costs (Copp et al. 2021; Haubrock et al. 2021a). Furthermore, the invasion threat is expanding owing to globalization and climate change (Kim et al. 2021a; Mamun et al. 2018; Seebens et al. 2018). The experts suggest the most cost-effective strategy in their prevention of spread and invasion of the potentially invasive species to negative the future impacts of IAS (Diagne et al., 2021; Leung et al. 2002). The threats posed by the invasive species involve the decline of native biodiversity (Kim et al. 2019), extinction of threatened species, modifications to the critical cycles ensuring the sustainability of recipient ecosystem, physical habitat alterations, and damages to the installed infrastructure (Jarić et al. 2019; Pyšek et al. 2012).

Researchers believe that only a tiny portion of IAS has been illustrated so far, which indicates the possibility of a large number going undetected (Alexander et al. 2014; Jang et al. 2002). Therefore, it is becoming increasingly important to discuss the potentially invasive species that may become invasive if they could enter an ecosystem. The non-native fish species (NNFS) could enter the novel eco- 
systems through many entryways, with humans the most recurrent facilitators (Atique et al. 2020). Ideally, the most advantageous introduction pathways include intentional release, stocking for biocontrol, food, aquaculture, sports, conservation, aquarium escape, bait release, accidental release, and miscellaneous escapes e.g., from aquaculture ponds, ballast release etc. (Fuller 2003; Seebens et al. 2021).

Owing to the increasing trends of live organism trade, the introduction of new species for food, aesthetics, and game fishing, the inflow, and influence of IAS is projected to increase by 20 times in the next three decades (Sardain et al. 2019). Perhaps feeling the potentially imminent threats to the native biodiversity, the Korean Ministry of Environment (MOE) has recently started working on designating potential risky species and has consistently released and updated the list of potentially invasive species that could be highly damaging to the ecosystems if they invade the various ecosystems in South Korea. The updated list of alien alert species that could potentially become invasive in the future comprises a total of 300 potential risky species, including 25 mammals, 7 birds, 84 fish, one Mollusk, one Arthropod, 28 Amphibians, 22 reptiles, one insect, 32 spiders, and 99 plant species. This list is continuously updated following the latest trends, literature, and changing climatic conditions. This is important to mention that during this study, we have explored only 45 potential risky fish species following the list released by MOE in 2018. These species have been selected on various traits that could assist them in invading the Korean ecosystems once they land or enter the Peninsula through multiple means. Here, we discuss the salient invasion features of the 45 fish species that could be the new invaders in South Korean aquatic ecosystems and how they could thrive after their arrival.

\section{Potential Reasons for Selection as Potential Invaders}

It is important to pinpoint why these fish species have been selected as the potential risky species and the species of interest having a greater potential to become an invasive or a pest in the Korean freshwater ecosystems. When an exotic species is introduced or gets a chance to enter a novel ecosystem matching their climatic and habitat requirements, they can quickly establish, reproduce and spread to the most favoring areas of the ecosystem to become IAS. Therefore, a species that can successfully endure these phases of the invasion process can become an insidious threat to native biodiversity. Concomitantly, the influx of potential risky species can adversely affect by causing severe damage, such as ecosystem disruption, destruction of feeding, breeding, habitat grounds, economic losses, and human health damages (Bomford 2008; Son et al. 2021).
The other reasons for selecting the potential risky alien fish species are the disturbing climate changes and habitat fragmentation affecting the native species and making room for IAS. Most of the risky fish species are already either invasive or introduced in the neighboring countries for several reasons, including aquaculture, filling the ecological niches, ornamental, public aquariums, and game fishing purposes to support the local fisheries and aquaculture industries. This also explains that the fish species can become invasive and established species upon entrance into the Korean Peninsula. The neighboring countries screened for the potential risky fish species include Japan, China, Vietnam, the Philippines, Thailand, and other nearby states where regular trade occurs to and from South Korea. The rapid and unrestrained influx of IAS can render the typical feeding and breeding grounds inescapable for the native fish species more vulnerable and detrimental, allegedly causing a decline in native fish biodiversity. Therefore, these species are already posing an extremely severe threat to the countries where they are present. Other reasons to keep these fish species on the list include keeping them on the watch list at the borders so that their entries through legal pathways could be restricted and monitored to control their introduction and potential spreads.

Furthermore, it is also significant to mention that the researchers should be vigilant while conducting the field surveys. Suppose they detect any samples of these fish species. In that case, they can report to the relevant expert authorities to take the necessary steps to control their spread and eradicate them before establishing viable populations. This is also one step ahead to save the Korean government's billions of national exchequer on control and eradication costs. Like most nations, Korea is also a signatory of the Convention on Biological Diversity (CBD) to improve the general understanding of fish biodiversity. This is due to the public's direct involvement for awareness purposes. Therefore, it is essential to identify and monitor the possible IAS entry pathways, along with the screening of potential risky alien fish species for timely management and control to avoid the future crises of established IAS communities (SCBD 2014).

\section{What Makes an Invasive Species Successfull in a Novel Envirronment?}

IAS are regarded as the leading threats to native biodiversity as nearly 42 percent of the native threatened or endangered species could be at risk due to the alien invasive species. Invasive species are characterized by their essential ability to adapt to new habitats, reproduce successfully and quickly establish thriving populations, and are harmful to the native fauna and flora (Mollot et al. 2017; Vitousek et al. 1997), and may inflict ecological and economic damage. 
Among the multiple effects of a successful invasive species, it must have spread to the novel ranges, have massive environmental and economic consequences by threatening the human services rendered by the ecosystem (Emery-Butcher et al. 2020). Some of the most crucial factors that help establish viable fish populations are the climate match with the native and novel area, prior success as invasive species, higher trophic plasticity, being attractive for multiple human uses (commercial fisheries, aquaculture, game fishing, ornamental trade), and have lower absolute fecundity rate (Cambray 2003; Chan et al. 2021). Therefore, it can be summed up that if a species can harm the new ecosystem structure, quality, and physical habitat, it can pose a severe threat to human health and economy, can grow and reproduce rapidly, have the ability to establish viable populations, can spread even aggressively and cause a decline of native species are successful invaders. One of the essential factors apart from the availability of feeding and breeding grounds is the adaptability to new climates and temperatures. If an ecosystem is vulnerable to environmental variations and is prone to degradation, invasive species may have a higher success rate. Besides, the absence of any external threats, less palatability, and lack of top predators in the new ecosystem can further assist them in establishing far-reaching populations. If the native fish species can not compete with the invading species for space, food, and defense to tackle predation by the invaders can further aggravate the conditions for natives and tilt the essential factors in favor of the establishment of invasive species. South Korea is consistently facing the severe threat of rapidly shifting climatic features causing the decline of native fish populations by disturbing their natural spawning and concomitant recruitment of the next generation. Simultaneously, it creates space for the invasion of other species by providing them ample opportunities to establish their populations and expand their range (Kim et al. 2021b).

\section{List of Fish Species Considered to be Potentially Invasive in Future}

Below is the list of 45 potential risky fish species that could become invasive if ever introduced or imported for any purpose (Table 1). The information on salient features of potentially dangerous fish species is mainly summarized from the Fish base and some other invasive species databases such as United States Fish and Wildlife Service (USFSW), Centre for Agriculture and Bioscience International (CABI), and Animal Diversity Web (ADW) for precise information on most of the species. Some of the endemic species in Japan were assessed based on the information provided by Japanese researchers. Most of these potentially risky fish species are already declared invasive elsewhere out of their native ranges and are mainly native to North America and Asia. The majority of the species (although native to North America) are already declared invasive in the neighboring nations of South Korea (including Japan and Thailand), which pose an even greater risk of invasions if they are successful in entering by any of the invasion pathways. The potential risky fish species are compiled here by their family, native ranges, most preferred aquatic biomes, feeding niches, current status in Korea (introduced or established or absent), along with potential threats to humans. This information aims to inform the researchers and public about the importance of restricting their entry and eradication urgency upon introduction, followed by establishing Korean freshwater ecosystems.

\section{Known Impacts of Potential Risky Alien Fish Species}

Lengthy details are published on introducing exotic fish species to novel freshwater ecosystems, which has accelerated in the recent decades (Cucherousset and Olden 2011). The introduction of alien fish species and their invasion continuously imperil endangered and threatened biodiversity (Kim et al. 2021a). Numerous studies highlight the emerging IAS and their ecological impacts on recipient ecosystems and biodiversity. Most alien fish pose a severe threat to the native biodiversity, mainly fish. Invasive alien fish species are increasingly contributing to higher extinction threats to freshwater biodiversity, especially fish, along with a synergistic pattern of habitat fragmentation loss, altered flow, shifting climatic conditions, pollution and overexploitation (Dudgeon et al. 2006). They are equally threatening to the already periled fish species, such as threatened and endangered species facing the daunting challenge of survival. This is a common observation that an exotic species actively compete with the native species for food, space, shelter and impact the spawning grounds and early life stages of the native species jeopardizing the native biodiversity and abundance (Al-Chokhachy and Sepulveda 2019). Keeping the details mentioned earlier in consideration, we enlist some of the most critical ecological impacts the potential risky exotic fish species may have on the native fish fauna in South Korea.

1. Micropterus dolomieu is known for its strong negative impact on native fish species and depletes the native fish biodiversity and abundance, as reported by Weyl et al. (2013) in South Africa.

2. Siniperca chuatsi is a demersal piscivorous fish species. They have developed specialized feeding methods mainly preying upon the fry of other fish species, thereby leading to declining fish biodiversity and abundance (Liang et al. 1998).

3. Gambusia affinis can negatively impact aquatic bio- 


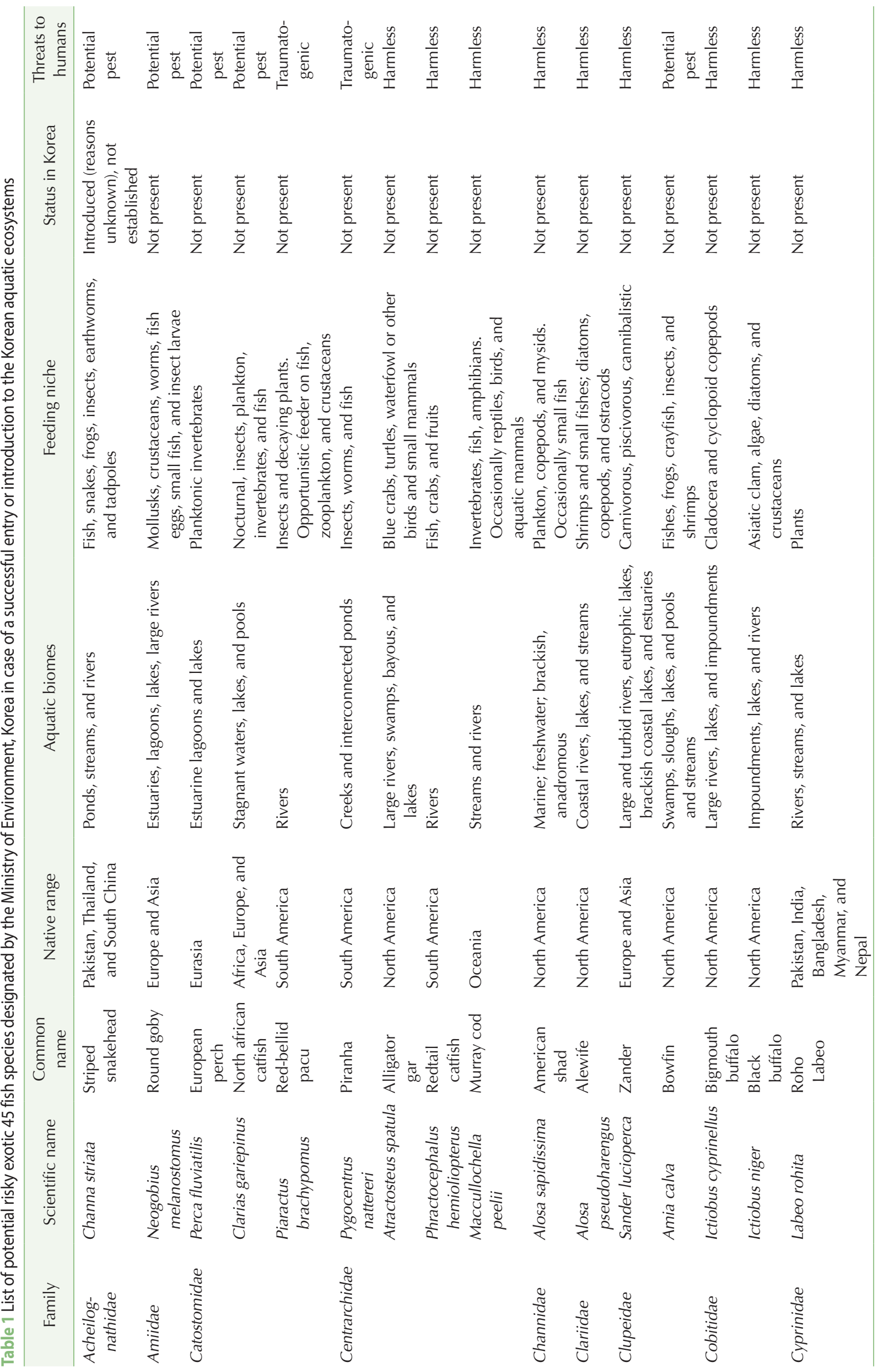




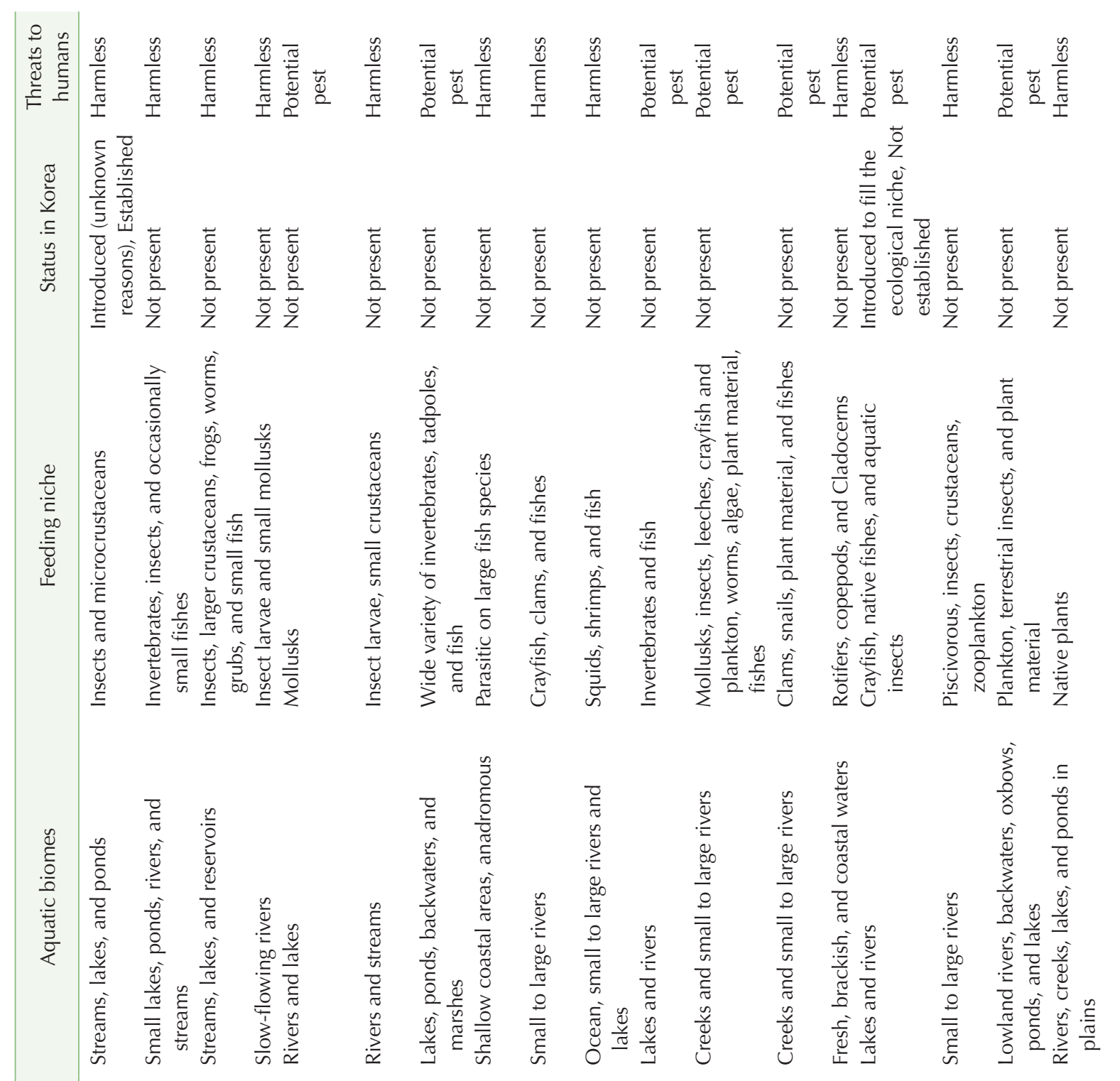

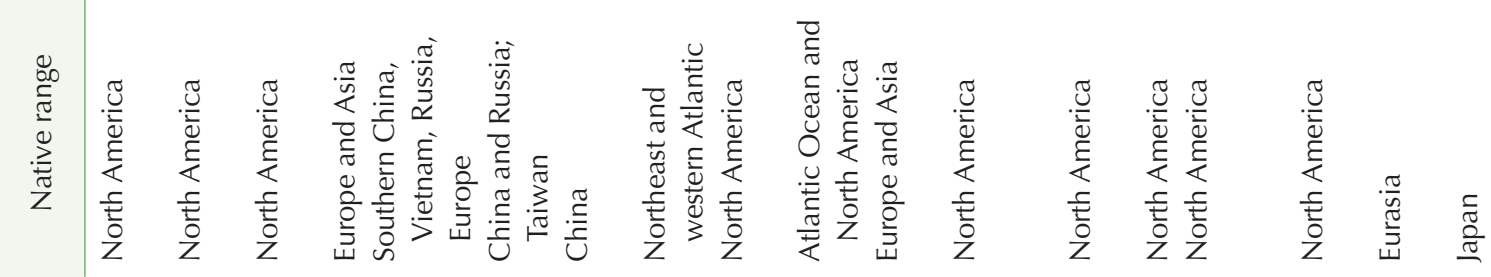

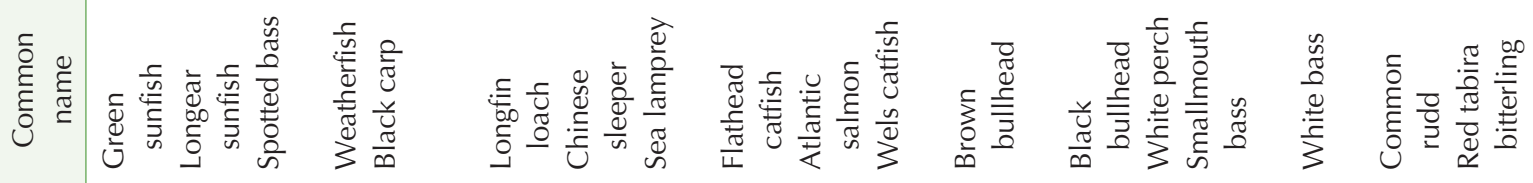

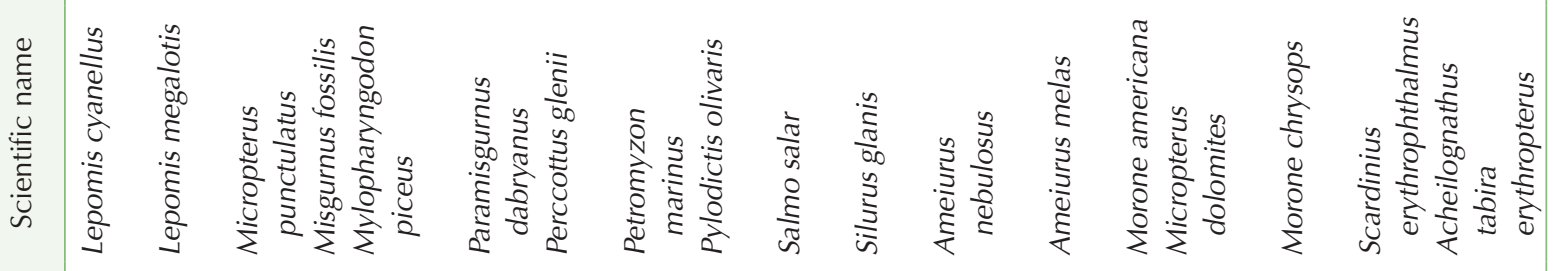




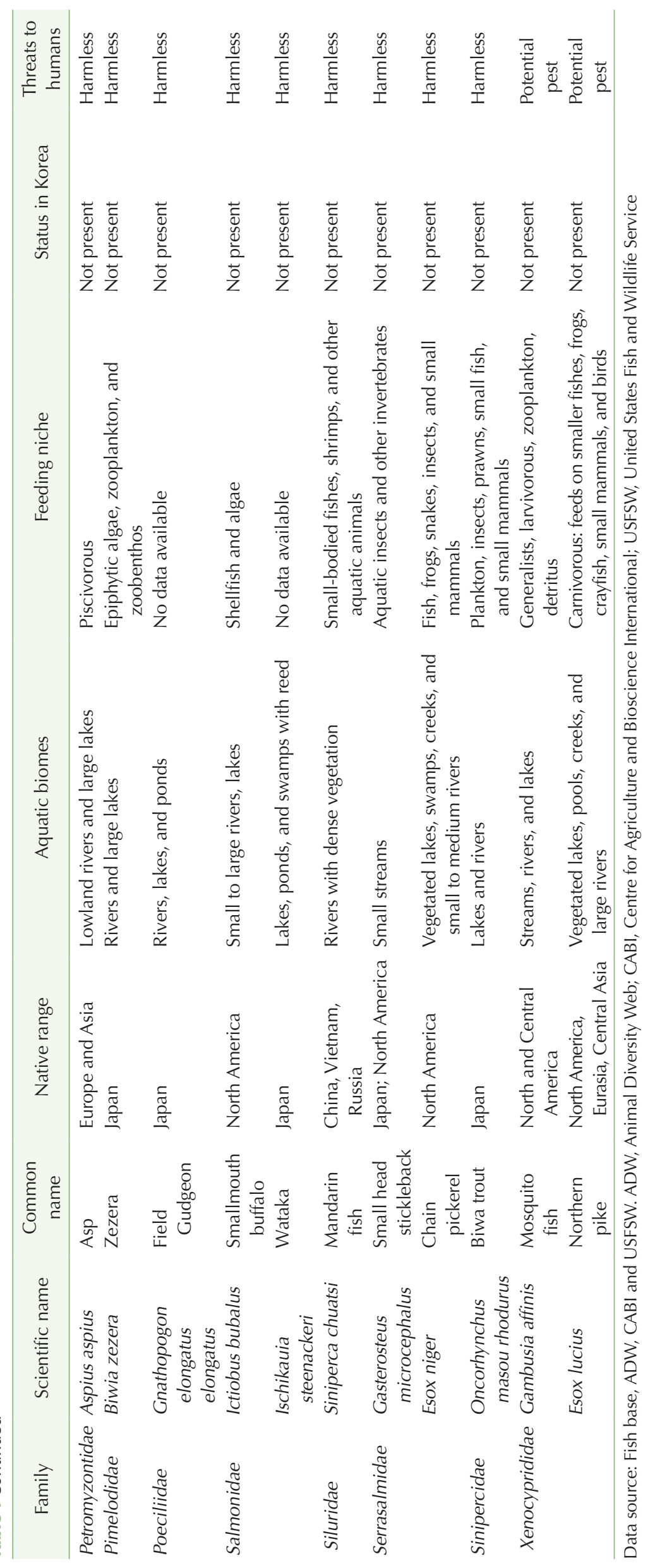


diversity, feed on or wound other small native fish species, and destroy them through competition (Haas et al. 2003). It is also known to affect the rare/protected species and the native fauna (including frogs).

4. Esox Lucius can significantly impact biodiversity by altering fish communities through competition and predation.

5. Channa striata can significantly alter the native fish biodiversity and aquatic fauna in the invaded ecosystem as it is a strong predator and can survive under harsh environmental conditions (Davidson 1975).

6. Neogobius melanostomus has led to diet shifts among predatory species and changed the food web composition (Bzoma and Stempniewicz 2001). Furthermore, it negatively impacts the native fish recruitment in Great Lakes and strongly competes for food and shelter with native species (Corkum et al. 2004).

7. Perca fluviatilis: As it feeds on fish, macroinvertebrates, and zooplankton, it can significantly alter the native freshwater communities (Closs et al. 2003).

8. Clarias gariepinus: It can generally harm biodiversity, ecosystem, and native fauna.

9. Piaractus brachypomus: They can negatively impact the ecosystem, especially stressful dry season conditions, as they switch to the opportunistic feeding mode on small fish, zooplankton, and crustaceans.

10. Pygocentrus nattereri: There are no known adverse impacts of this species reported.

11. Atractosteus spatula: There are no documented reports on the negative impacts of gar; however, it is highly likely to damage the native fish fauna if it is introduced.

12. Phractocephalus hemioliopterus: Currently unknown.

13. Maccullochella peelii: There are no documented reports on the negative impacts.

14. Alosa sapidissima: There are no documented adverse effects on native species of the introduced ecosystems.

15. Alosa pseudoharengus: They negatively impact fish biodiversity by size-selective predation on zooplankton species by eliminating the most prominent species and alter dominance to the small-sized species (Johannsson 2003; Wells 1970). Further, the impact by preying on native fish species pelagic larvae causing a sharp curtail in the recruitment of native fish species (Madenjian et al. 2008), and by causing thiamine deficiency in salmonids preying mainly on $A$. pseudoharengus, which results in lower reproductive accomplishment (Gnaedinger 1964).

16. Amia calva: There are no documented reports on the negative impacts of gar; however, it is highly likely to damage the native fish fauna if it is introduced, as they are voraciously piscivorous.

17. Sander lucioperca: It can result in reduced populations of native prey and contender fish species. It may also cause trophic shifts and extirpation of native fish species (Müller et al. 2010).

18. Ictiobus cyprinellus: It may compete with native fish species for food and space if it becomes invasive or is introduced (Moyle 1976).

19. Ictiobus niger: Currently unknown.

20. Labeo rohita: There are no documented reports on the negative impacts, nor is there a recorded history of invasiveness of this species.

21. Lepomis cyanellus: It competes with and preys upon the native fish species, leading $t$ to the decline and alter their population structure and distribution patterns (Olden and Poff 2005).

22. Lepomis megalotis: Currently unknown.

23. Micropterus punctulatus: It can hybridize with smallmouth bass and potentially pose trophic competition to the top predators in the food chain (Whitmore 1983).

24. Misgurnus fossilis: It is a strong competitor and predator; therefore, it can pose a grave threat to the trophic chain and population structure if introduced.

25. Mylopharyngodon piceus: It has a higher potential to negatively impact the native fish communities through food, space of the endangered or threatened species (Nico and Neilson 2011).

26. Paramisgurnus dabryanus: Reportedly can compete and hybridize with native weatherfish species in Japan.

27. Perccottus glenii: It is a voracious predator with specialized morphological features that help hunting various aquatic species leading to the decline of native aquatic biodiversity and disturbed trophic structure (Miller and Vasil'eva 2003).

28. Petromyzon marinus: being parasitic, they can enormously damage several native and commercial fish species.

29. Pylodictis olivaris is an aggressive predator on large and top predatory fish species; therefore, it is highly likely to cause a decline in native top-predator fish species (Quinn 1987).

30. Salmo salar: It generally negatively impacts the native fish fauna and their ecosystems if introduced.

31. Silurus glanis: This catfish may impact the native fish fauna by increasing competition for indigenous and critically endangered fish habitats and switching to the most appropriate food resources for their feeding (Martino et al. 2011).

32. Ameiurus nebulosus: It can decrease the abundance and diversity of exotic and native predators where introduced (Hughes and Herlihy 2012).

33. Ameiurus melas: It directly or indirectly impacts introduced habitat through increased turbidity, reduced substrate stability, competition, and predation of native species (Leunda et al. 2008; Rosen et al. 1995).

34. Morone americana: It competes for food and shelter with the native fish species, therefore can negatively impact native biodiversity and cause a decline (Fuller 
et al. 2008).

35. Morone chrysops: This intermediate predator can negatively impact the small native fish species and their abundance (Schultz 2004).

36. Scardinius erythrophthalmus is a potential pest for its fast consumption of aquatic plants, leading to the decline of vulnerable native aquatic plant species (Lake et al. 2002).

37. Acheilognathus tabira erythropterus: They compete with the native bitterling species for egg deposition during spawning; therefore, it may lead to decreased reproductive success, ultimately causing particular species decline (Froese and Pauly 2011).

38. Aspius aspius: Except for hybridization with native fish species (Leuciscus idus), no other adverse impacts are reported (Kottelat and Freyhof 2007).

39. Biwia zezera: They are known for hybridizing native fish species (Froese and Pauly 2011).

40. Gnathopogon elongatus elongatus: Currently unknown.

41. Ischikauia steenackeri: Currently unknown.

42. Ictiobus bubalus: Currently unknown.

43. Esox niger: Ther are suspected of hybridizing and impacting native species by competition, especially threatened and endangered fish species (Herke et al. 1990).

44. Gasterosteus microcephalus: It eats the native fish species eggs and larvae and competes with them for food and space, thereby leading to the decline of native fish species where introduced (Wisconsin SeaGrant 2016).

45. Oncorhynchus masou rhodurus: Currently unknown.

\section{Potentially Tempting Factors of Fish Introduction}

There is a general review that the introductions of invasive alien fish species are primarily harmful to the native biodiversity (Segev et al. 2009; Townsend 2003). However, there also have been discussions surrounding the impacts of IAS, characterizing them all bad (Gozlan 2008) and vice versa (Vitule et al. 2009). Based on the literature search for the current list of potential lrisky fish species in Korea, it was found that most fish species invasions were purposefully mediated by humans for aquaculture, ornamental, catch fisheries, filling the ecological niche, biocontrol, and game fishing. Some were also accidental, such as escape from aquaculture and ornamental facilities. Below are the potentially compelling reasons that could be the leading reasons for the intentional introduction of the potentially risky 45 exotic fish species. Therefore, it is important to highlight that while screening the new fish species as potential risky species in the future, these factors and possible uses must be carefully considered. Most fish species are either well-known for the commercial fisheries potential, game fishing, highly commercial aquaculture prospects, public display in aquariums, and rare cases, could be used as a biological control agent, which could be even more detrimental to the whole aquatic biodiversity. The data presented here was mainly modified from the Fish base.

1. Micropterus dolomieu: Commercial fisheries, gamefish, public aquariums.

2. Siniperca chuatsi: Popular food fish, commercial fisheries, aquaculture.

3. Gambusia affinis: Used as a biocontrol agent for mosquitoes; however, it has been rarely proven. It is also used as a live feed and for ornamental purposes.

4. Esox Lucius: Highly commercial fisheries and aquaculture, gamefish, and public aquariums.

5. Channa striata: Highly commercial fisheries and aquaculture, public aquariums.

6. Neogobius melanostomus: Commercial fisheries, commercial aquarium, and occasional bait.

7. Perca fluviatilis: Highly commercial fisheries and aquaculture, gamefish.

8. Clarias gariepinus: Minor commercial fisheries, commercial aquaculture, and gamefish.

9. Piaractus brachypomus: Minor commercial fisheries, commercial aquaculture, and aquarium.

10. Pygocentrus nattereri: Little commercial fisheries, commercial aquarium.

11. Atractosteus spatula: Minor commercial fisheries, gamefish, and aquarium fish.

12. Phractocephalus hemioliopterus: Minor commercial fisheries, gamefish, and aquarium fish.

13. Maccullochella peelii: Highly commercial fisheries and aquaculture, gamefish.

14. Alosa sapidissima: Highly commercial fisheries and gamefish.

15. Alosa pseudoharengus: Highly commercial fisheries, baitfish.

16. Amia calva: Gamefish and public aquariums.

17. Sander lucioperca: Highly commercial fisheries and aquaculture, gamefish, and public aquariums.

18. Ictiobus cyprinellus: Minor commercial fisheries, commercial aquaculture, and gamefish.

19. Ictiobus niger: Minor commercial fisheries, commercial aquaculture, and gamefish.

20. Labeo rohita: Highly commercial fisheries and aquaculture, gamefish.

21. Lepomis cyanellus: Highly commercial aquaculture and gamefish.

22. Lepomis megalotis: Public aquariums.

23. Micropterus punctulatus: Gamefish.

24. Misgurnus fossilis: Noncommercial fisheries, baitfish.

25. Mylopharyngodon piceus: Highly commercial fisheries and aquaculture.

26. Paramisgurnus dabryanus: Highly commercial aquaculture. 
27. Perccottus glenii: Small commercial fisheries with potential aquarium usage.

28. Petromyzon marinus: Small commercial fisheries.

29. Pylodictis olivaris: Gamefish and public aquariums.

30. Salmo salar: Highly commercial fisheries and aquaculture, gamefish.

31. Silurus glanis: Highly commercial fishing and aquaculture, gamefish.

32. Ameiurus nebulosus: Minor commercial fisheries, commercial aquaculture, and gamefish.

33. Ameiurus melas: Highly commercial fishing and aquaculture, gamefish.

34. Morone americana: Small commercial fisheries, gamefish, and public aquariums.

35. Morone chrysops: Experimental and aquaculture and gamefish.

36. Scardinius erythrophthalmus: Minor commercial fisheries, commercial aquaculture, gamefish, commercial aquarium, and a routine bait.

37. Acheilognathus tabira erythropterus: No particular interest of humans.

38. Aspius aspius: Highly commercial fisheries and aquaculture, gamefish.

39. Biwia zezera: No particular interest of humans.

40. Gnathopogon elongatus elongatus: No particular interest of humans.

41. Ischikauia steenackeri: No particular interest of humans.

42. Ictiobus bubalus: Highly commercial fisheries and gamefish.

43. Esox niger: Gamefish.

44. Gasterosteus microcephalus: Noncommercial fisheries.

45. Oncorhynchus masou rhodurus: Commercial fisheries.

\section{Discussion}

Freshwater fisheries play a vital role in many aspects of human societies especially providing high-quality proteins to the poor fisher communities in developing countries (Ray et al. 2021). In the preceding two decades, there has been an awakening about checking the introduction and spread of IAS in most countries. The International Union of Conservation of Nature (IUCN) has indexed some of the leading IAS, which has not served the intended purpose to manage the entry and influx of IAS across the world. The list was recognized as the 'world's 100 worst IAS' as part of the global recognition of the issue and awareness about the management across the globe (IUCN 2000). The neighboring nation of Japan designated the alien species by promulgating an act viz. IAS act in 2005. Following this, there are now 145 IAS set species along with other types (Kil et al. 2015). According to Xu et al. (2012), there is an IAS inventory in China comprising 734 species managed under the
'Chinese Biodiversity Conservation Action Plan'.

The United Kingdom established a plan as 'Great Britain Invasive Non-Native Species Strategy' in 2013 to devise their strategy for controlling IAS, and designated 142 species as legitimately forbidden in UK (GB Non-Native Species Secretariat 2016). Similarly, New Zealand manages 969 species by blocking them through their inventory in a clean list based on the Biosecurity act in 1993 (Brenton-Rule et al. 2016). Various federating states of the United States of America promote the integrated management of 2,873 species through their Clean and Dirty Lists. The dirty list recorded the IAS under the Federal Noxious Weed Act passed by the US congress in 1993 (US Department of Agriculture 2010). Norway has prepared a list of 2,595 species on their Norwegian Black List, which is further subdivided into 1,180 IAS capable of breeding in Norway with 203 as the door knockers, while 106 species are considered to have a severe impact in Norway (Gederaas et al. 2012). The European Network on Invasive Alien Species has designated 496 species in North and Central Europe, while Australia enlisted 563 IAS to control their influx.

Similarly, a total of 1,109 introduced exotic species were reported in 2011, which almost doubled up to 2,160 species within a short period of two years in 2013 (Kil and Kim 2014). The MOE has notified the variety of IAS into various groups viz. mammals, fish, amphibians, birds, reptiles, plants, insects, and invertebrates as per the notification of MOE (Ministry of Environment notification 2017). Considering the alarming situation, the new act on conservation and use of biological diversity was promulgated in 2013 and amended in 2019 to manage the increasing influx of IAS. This act duly defined the IAS as disturbing or likely to disturb the ecological system balance, therefore requiring approval for import and transfer for domestic inflow. As a result of this activity, a list of potential risky alien species was prepared by the leading scientists across the country and updated annually.

To construct the list of these species, data on harmful ecological features, physiological characteristics, and case studies in case of harmful impacts in the invaded ecosystems were duly considered. The four leading criteria for designating any species as IAS included being recognized globally as a risky species and can inflict ecological, economic, and social damages. It was further assessed if they have identical genetic compositions with similar environmental and climatic requirements. Suppose there are chacnes of these characteristics among the potential risky species. In that case, they must have a high probability of establishment if conducive climatic conditions and suitable habitat matches are available. Based on these four features, potential risky species were designated in South Korea.

There has been an increasing number of investigations on the economic costs of managing the IAS in various countries (Crystal-Ornelas et al. 2021; Haubrock et al. 
2021b). A considerably large amount of funds are being spent by many countries to effectively tackle the influx of IAS around the world (Luque et al. 2014). For instance, the case of common carp invasion costs approximately 12 million US dollars per annum to control the damages inflicted to native fish diversity, invertebrates, and plants (McLeod 2004). Therefore, it is becoming increasingly essential to efficiently maintain the influx of IAS to manage the prevention and control costs. Perhaps the most compelling reason the advanced nations have resorted to preparing potential risky species lists. Therefore, it is necessary to be proactive about the new invasions before they enter and establish viable populations. Furthermore, the list of potential risky species must be regularly updated to manage the emerging IAS actively.

\section{Conclusions}

Exotic species spread and establishment have emerged as a global challenge and are the most persistent and devastating threat to native biodiversity worldwide. This study highlights the basic features of potential risky exotic fish species in South Korea. The researchers agree that the most cost-effective strategy to control the invasive species is to prevent their spread and establishment. Anticipating the threat, the Korean Ministry of Environment took the initiative and released an inventory list of potential risky exotic species. The lists are regularly updated with the help of experts. Based on the updated list released in 2021, the number of potential risky fish species has almost doubled to 84 compared with 45 risky species apprised in 2018. This illustrates that the threat of potential risky fish species is real and imminent as these exotic fish species could become highly risky to the native fish biodiversity in the future. Most fish species are either native or already declared established in the neighboring countries. They have solid commercial fisheries and higher aquaculture potential, along with their demand in the aquarium display. Most fish species can lead to substantial economic costs and damage the native aquatic biodiversity based on their feeding niche, high fecundity rates, higher climate matches to their native ranges, and history of successful success invasions in the past. Therefore, it is imperative to screen all the new species for their invasive potential and concomitant ecological damages before being regulated for entry into the Korean Peninsula.

\section{Supplementary Information}

Supplementary information accompanies this paper at https://doi.org/10.1186/jee.22.008.

Additional file 1: Supplementary Material: Main refer- ence.

\author{
Abbreviations \\ IAS: Invasive alien species \\ NNS: Non-native species \\ NNFS: Non-native fish species \\ MOE: Ministry of Environment \\ USFWS: United States Fish and Wildlife Service \\ CABI: Centre for Agriculture and Bioscience International \\ ADW: Animal Diversity Web
}

\section{Acknowledgements}

This research was supported by the 'Korea Environment Industry \& Technology Institute (KEITI)' through "Exotic Invasive Fish Species Management Project", funded by the Ministry of Environment, Korea, and by Daejeon Green Environment Center under the Research Development Program (Yr 2016). Therefore, the authors would like to acknowledge for their support.

\section{Authors' contributions}

UA collected the required information, designed the study, wrote and revised the manuscript under the supervision of Prof. KGA.

\section{Funding}

This work was supported by "Korea Environment Industry \& Technology Institute (KEITI)" through the "Exotic Invasive Fish Species Management Project," funded by the Ministry of Environment, Korea (Grant No.: 2018002270003, RE201807019).

\section{Availability of data and materials \\ Not applicable.}

\section{Ethics approval and consent to participate \\ Not applicable.}

\section{Consent for publication}

Not applicable.

\section{Competing interests}

The authors declare that they have no competing interests.

\section{References}

Al-Chokhachy R, Sepulveda AJ. Impacts of nonnative Brown Trout on Yellowstone Cutthroat Trout in a tributary stream. N Am J Fish Manag. 2019;39(1):17-28. https://doi.org/10.1002/nafm.10244.

Alexander ME, Dick JT, Weyl OL, Robinson TB, Richardson DM. Existing and emerging high impact invasive species are characterized by higher functional responses than natives. Biol Lett. 2014;10(2): 20130946. https://doi.org/10.1098/rsbl.2013.0946.

Atique U, Kwon S, An KG. Linking weir imprints with riverine water chemistry, microhabitat alterations, fish assemblages, chlorophyll-nutrient dynamics, and ecological health assessments. Ecol In- 
dic. 2020;117:106652. https://doi.org/10.1016/j.ecolind.2020.106652.

Bomford M. Risk assessment models for establishment of exotic vertebrates in Australia and New Zealand. Canberra: Invasive Animals Cooperative Research Centre; 2008.

Brenton-Rule E, Frankel S, Lester P. Improving management of invasive species: New Zealand's approach to pre- and post-border pests. Policy Q. 2016;12(1):17-25. https://doi.org/10.26686/pq.v12i1.4582.

Bzoma S, Stempniewicz L. Great cormorants (Phalacrocorax carbo) diet in the Gulf of Gdansk in 1998. In: Piekarek-Jankowska H, editors. Proceedings of the Third International Symposium on Functioning of coastal ecosystems in various geographical regions, held in Gdynia, Poland, on 19-22 June 2001. Gdańsk: Institute of Oceanography, University of Gdańsk; 2001.

Cambray JA. Impact on indigenous species biodiversity caused by the globalisation of alien recreational freshwater fisheries. Hydrobiologia. 2003;500(1):217-30. https://doi.org/10.1023/A:1024648719995.

Chan J, Zeng Y, Yeo DCJ. Invasive species trait-based risk assessment for non-native freshwater fishes in a tropical city basin in Southeast Asia. PLoS One. 2021;16(3):e0248480. https://doi.org/10.1371/journal.pone. 0248480

Closs GP, Ludgate B, Goldsmith RJ. Controlling European perch (Perca fluviatilis): lessons from an experimental removal. In: New Zealand Department of Conservation, editor. Managing invasive freshwater fish in New Zealand proceedings of a workshop hosted by department of conservation, 10-12 May 2001, Hamilton. Wellington: New Zealand Department of Conservation; 2003. p. 37-48.

Copp GH, Vilizzi L, Wei H, Li S, Piria M, Al-Faisal AJ, et al. Speaking their language- development of a multilingual decision-support tool for communicating invasive species risks to decision makers and stakeholders. Environ Model Softw. 2021;135:104900. https://doi. org/10.1016/j.envsoft.2020.104900.

Corkum LD, Sapota MR, Skora KE. The round goby, Neogobius melanostomus, a fish invader on both sides of the Atlantic Ocean. Biol Invasions. 2004;6(2):173-81. https://doi.org/10.1023/B:BINV.0000022136. 43502.db.

Crystal-Ornelas R, Hudgins EJ, Cuthbert RN, Haubrock PJ, Fantle-Lepczyk J, Angulo E, et al. Economic costs of biological invasions within North America. NeoBiota. 2021;67:485-510. https://doi.org/10. 3897/neobiota.67.58038

Cucherousset J, Olden JD. Ecological impacts of nonnative freshwater fishes. Fisheries. 2011;36(5):215-30. https://doi.org/10.1080/036324 15.2011.574578.

Cuthbert RN, Diagne C, Haubrock PJ, Turbelin AJ, Courchamp F. Are the "100 of the world's worst" invasive species also the costliest? Biol Invasions. 2021. https://doi.org/10.1007/s10530-021-02568-7.

Davidson A. Fish and fish dishes of Laos. Vientiane: Imprimerie Nationale; 1975.

Diagne C, Leroy B, Vaissière AC, Gozlan RE, Roiz D, Jarić I, et al. High and rising economic costs of biological invasions worldwide. Nature. 2021;592(7855):571-6. https://doi.org/10.1038/s41586-021-03405-6.

Dudgeon D, Arthington AH, Gessner MO, Kawabata Z, Knowler DJ, Lévêque $\mathrm{C}$, et al. Freshwater biodiversity: importance, threats, status and conservation challenges. Biol Rev Camb Philos Soc. 2006;81(2): 163-82. https://doi.org/10.1017/S1464793105006950.
Emery-Butcher HE, Beatty SJ, Robson BJ. The impacts of invasive ecosystem engineers in freshwaters: a review. Freshw Biol. 2020;65(5): 999-1015. https://doi.org/10.1111/fwb.13479.

Froese R, Pauly D. FishBase. 2011. http://www.fishbase.org. Accessed 11 Nov 2021.

Fuller P, Maynard E, Raikow D, Larson J, Fusaro A, Neilson M. Morone americana. 2008. https://nas.er.usgs.gov/queries/factsheet.aspx?SpeciesID=777. Accessed 11 Nov 2021.

Fuller PL. Freshwater aquatic vertebrate introductions in the United States: patterns and pathways. In: Ruiz GM, Carlton J, editors. Invasive species: vectors and management strategies. Washington D.C.: Island Press; 2003. p. 123-34.

GB Non-Native Species Secretariat. GB non-native species information portal. 2016. http://www.nonnativespecies.org/factsheet/. Accessed 2 May 2016.

Gederaas L, Moen TL, Skjelseth S, Larsen LK. Alien species in Norway - with the Norwegian Black List 2012. Trondheim: The Norwegian Biodiversity Information Centre; 2012.

Gnaedinger RH. Thiaminase activity in fish: an improved assay method. Fish Ind Res. 1964;2:55-9.

Gozlan RE. Introduction of non-native freshwater fish: is it all bad? Fish Fish. 2008;9(1):106-15. https://doi.org/10.1111/j.1467-2979.2007. 00267.x.

Haas RC, Thomas MV, Towns GL. An assessment of the potential use of Gambusia for mosquito control in Michigan. Technical Report 20032. Lansing: Michigan Department of Natural Resources Fisheries Division; 2003.

Haubrock PJ, Pilotto F, Innocenti G, Cianfanelli S, Haase P. Two centuries for an almost complete community turnover from native to non-native species in a riverine ecosystem. Glob Change Biol. 2021a;27(3):606-23. https://doi.org/10.1111/gcb.15442.

Haubrock PJ, Turbelin AJ, Cuthbert RN, Novoa A, Taylor NG, Angulo E, et al. Economic costs of invasive alien species across Europe. NeoBiota. 2021b;67:153-90. https://doi.org/10.3897/neobiota.67.58196.

Herke SW, Kornfield I, Moran P, Moring JR. Molecular confirmation of hybridization between northern pike (Esox lucius) and chain pickerel (E. niger). Copeia. 1990;1990(3):846-50. https://doi.org/10.2307/1446451.

Hughes RM, Herlihy AT. Patterns in catch per unit effort of native prey fish and alien piscivorous fish in 7 Pacific Northwest USA rivers. Fisheries. 2012;37(5):201-11. https://doi.org/10.1080/03632415.201 2.676833 .

International Union for Conservation of Nature (IUCN). IUCN guidelines for the prevention of biodiversity loss caused by alien invasive species. Auckland: Species Survival Commission; 2000.

Jang MH, Kim JG, Park SB, Jeong KS, Cho GI, Joo GJ. The current status of the distribution of introduced fish in large river systems of South Korea. Int Rev Hydrobiol. 2002;87(2-3):319-28. https://doi. org/10.1002/1522-2632(200205)87:2/3<319::AID-IROH319>3.0.CO;2-N.

Jarić I, Heger T, Castro Monzon F, Jeschke JM, Kowarik I, McConkey KR, et al. Crypticity in biological invasions. Trends Ecol Evol. 2019;34(4):291-302. https://doi.org/10.1016/j.tree.2018.12.008.

Johannsson OE. A history of changes in zooplankton community structure and function in Lake Ontario: responses to whole-lake remediation and exotic invasions. In: Munawar M, editor. State of Lake On- 
tario: past, present and future. Burlington: Aquatic Ecosystem Health and Management Society; 2003. p. 221-56.

Kil JH, Kim CG. Overview of preventive measures against invasive alien species in Korea and suggestions for their improvement. Korean J Ecol Environ. 2014;47(4):239-46. https://doi.org/10.11614/KSL. 2014.47.4.239.

Kil JH, Mun S, Kim CG. Risk assessment tools for invasive alien species in Japan and Europe. Ecol Resil Infrastruct. 2015;2(3):191-7. https:// doi.org/10.17820/eri.2015.2.3.191

Kim JJ, Atique U, An KG. Key drivers influencing the presence and absence of Micropterus salmoides and their effect on native fish communities and biotic integrity. Water. 2021;13(23):3430. https://doi. $\operatorname{org} / 10.3390 /$ w13233430.

Kim JJ, Atique U, An KG. Long-term ecological health assessment of a restored urban stream based on chemical water quality, physical habitat conditions and biological integrity. Water. 2019;11(1):114. https://doi.org/10.3390/w11010114.

Kim JY, Atique U, An KG. Relative abundance and invasion dynamics of alien fish species linked to chemical conditions, ecosystem health, native fish assemblage, and stream order. Water. 2021b;13(2):158. https://doi.org/10.3390/w13020158.

Kottelat M, Freyhof J. Handbook of European freshwater fishes. Cornol: Publications Kottelat; 2007.

Lake MD, Hicks BJ, Wells RDS, Dugdale TM. Consumption of submerged aquatic macrophytes by rudd (Scardinius erythrophthalmus L.) in New Zealand. Hydrobiologia. 2002;470:13-22. https://doi. org/10.1023/A:1015689432289.

Leunda PM, Oscoz J, Elvira B, Agorreta A, Perea S, Miranda R. Feeding habits of the exotic black bullhead Ameiurus melas (Rafinesque) in the Iberian Peninsula: first evidence of direct predation on native fish species. J Fish Biol. 2008;73(1):96-114. https://doi.org/10.1111/ j.1095-8649.2008.01908.x.

Leung B, Lodge DM, Finnoff D, Shogren JF, Lewis MA, Lamberti G. An ounce of prevention or a pound of cure: bioeconomic risk analysis of invasive species. Proc Biol Sci. 2002;269(1508):2407-13. https://doi. org/10.1098/rspb.2002.2179.

Liang XF, Kiu JK, Huang BY. The role of sense organs in the feeding behaviour of Chinese perch. J Fish Biol. 1998;52(5):1058-67. https:/ doi.org/10.1111/j.1095-8649.1998.tb00603.x.

Luque GM, Bellard C, Bertelsmeier C, Bonnaud E, Genovesi P, Simberloff D, et al. The 100th of the world's worst invasive alien species. Biol Invasions. 2014;16(5):981-5. https://doi.org/10.1007/s10530013-0561-5.

Madenjian CP, O'Gorman R, Bunnell DB, Argyle RL, Roseman EF, Warner DM, et al. Adverse effects of alewives on Laurentian Great Lakes fish communities. N Am J Fish Manag. 2008;28(1):263-82. https:// doi.org/10.1577/M07-012.1.

Mamun M, Kim S, An KG. Distribution pattern prediction of an invasive alien species largemouth bass using a maximum entropy model (MaxEnt) in the Korean peninsula. J Asia Pac Biodivers. 2018;11(4): 516-24. https://doi.org/10.1016/j.japb.2018.09.007.

Martino A, Syväranta J, Crivelli A, Cereghino R, Santoul F. Is European catfish a threat to eels in southern France? Aquat Conserv Mar Freshw Ecosyst. 2011;21(3):276-81. https://doi.org/10.1002/aqc.1177.
McLeod R. Counting the cost: impact of invasive animals in Australia. Canberra: Pest Animal Control CRC; 2004.

Miller P, Vasil'eva ED. Perccottus glenii Dybowsky 1877. In: Miller PJ, editor. The freshwater fishes of Europe. Vol. 8, 1, mugilidae, atherinidae, atherinopsidae, blenniidae, odontobutidae, gobiidae 1. Wiebelsheim: AULA-Verlag; 2003. p. 135-56.

Ministry of Environment notification. Designation and notification of alert species. Sejong: Ministry of Environment; 2017.

Mollot G, Pantel JH, Romanuk TN. The effects of invasive species on the decline in species richness: a global meta-analysis. Adv Ecol Res. 2017;56:61-83. https://doi.org/10.1016/bs.aecr.2016.10.002.

Moyle PB. Inland fishes of California. Berkeley: University of California Press; 1976.

Müller T, Taller J, Kolics B, Kovács B, Urbányi B, Specziár A. First record of natural hybridization between pikeperch Sander lucioperca and Volga pikeperch S. volgensis. J Appl Ichthyol. 2010;26(3):481-4. https://doi.org/10.1111/j.1439-0426.2010.01463.x.

Nico LG, Neilson ME. Mylopharyngodon piceus (Richardson, 1846). 2011. http://nas.er.usgs.gov/queries/factsheet.aspx?SpeciesID=573. Accessed 12 Nov 2021.

Olden JD, Poff NL. Long-term trends of native and non-native fish faunas in the American Southwest. Anim Biodivers Conserv. 2005;28(1):75-89.

Pyšek P, Hulme PE, Simberloff D, Bacher S, Blackburn TM, Carlton JT, et al. Scientists' warning on invasive alien species. Biol Rev. 2020;95(6):1511-34. https://doi.org/10.1111/brv.12627.

Pyšek P, Jarošík V, Hulme PE, Pergl J, Hejda M, Schaffner U, et al. A global assessment of invasive plant impacts on resident species, communities and ecosystems: the interaction of impact measures, invading species' traits and environment. Glob Change Biol. 2012; 18(5):1725-37. https://doi.org/10.1111/j.1365-2486.2011.02636.x.

Quinn SP. Stomach contents of flathead catfish in the Flint River, Georgia. Proc Annu Conf Southeast Assoc Fish Wildl Agencies. 1987;41: 85-92.

Ray S, Mondal P, Paul AK, Iqbal S, Atique U, Islam MS, et al. Role of shrimp farming in socio-economic elevation and professional satisfaction in coastal communities. Aquac Rep. 2021;20:100708. https:// doi.org/10.1016/j.aqrep.2021.100708.

Rosen PC, Schwalbe CR, Parizek DA Jr, Holm PA, Lowe CH. Introduced aquatic vertebrates in the Chiricahua region: effects on declining native ranid frogs. In: DeBano LH, Ffolliott PH, Ortega-Rubio A, Gottfried GJ, Hamre RH, Edminster CB, editors. Biodiversity and management of the Madrean Archipelago: the sky islands of southwestern United States and northwestern Mexico. General Technical Report RM-GTR-264. Fort Collins: U.S. Department of Agriculture Forest Service; 1995. p. 251-61.

Sardain A, Sardain E, Leung B. Global forecasts of shipping traffic and biological invasions to 2050. Nat Sustain. 2019;2(4):274-82. https:// doi.org/10.1038/s41893-019-0245-y.

SCBD (Secretariat of the Convention on Biological Diversity). Global biodiversity outlook 4. Montreal: Secretariat of the Convention on Biological Diversity; 2014.

Schultz K. Ken Schultz's field guide to freshwater fish. Hoboken: Wiley; 2004. 
Seebens H, Bacher S, Blackburn TM, Capinha C, Dawson W, Dullinger $\mathrm{S}$, et al. Projecting the continental accumulation of alien species through to 2050. Glob Chang Biol. 2021;27(5):970-82. https://doi. org/10.1111/gcb.15333.

Seebens H, Blackburn TM, Dyer EE, Genovesi P, Hulme PE, Jeschke $\mathrm{JM}$, et al. Global rise in emerging alien species results from increased accessibility of new source pools. Proc Natl Acad Sci U S A. 2018;115(10):E2264-73. https://doi.org/10.1073/pnas.1719429115.

Segev O, Mangel M, Blaustein L. Deleterious effects by mosquitofish (Gambusia affinis) on the endangered fire salamander (Salamandra infraimmaculata). Anim Conserv. 2009;12(1):29-37. https://doi. org/10.1111/j.1469-1795.2008.00217.x.

Son SH, Jo AR, Kim DE. Current status of alert alien species management for the establishment of proactive management systems in Korea. J Ecol Environ. 2021;45:26. https://doi.org/10.1186/s41610-02100204-y.

Townsend CR. Individual, population, community, and ecosystem consequences of a fish invader in New Zealand streams. Conserv Biol. 2003;17(1):38-47.

US Department of Agriculture. Federal noxious weed list. Riverdale: US Department of Agriculture; 2010.

Vitousek PM, D’Antonio CM, Loope LL, Rejmánek M, Westbrooks R. Introduced species: a significant component of human-caused global change. N Z J Ecol. 1997;21(1):1-16.

Vitule JRS, Freire CA, Simberloff D. Introduction of non-native freshwater fish can certainly be bad. Fish Fish. 2009;10(1):98-108. https:// doi.org/10.1111/j.1467-2979.2008.00312.x.

Welcomme RL. International introductions of inland aquatic species. Rome: Food and Agriculture Organization of the United Nations; 1988.

Wells L. Effects of alewife predation on zooplankton populations in Lake Michigan. Limnol Oceanogr. 1970;15(4):556-65. https://doi.org/10. 4319/10.1970.15.4.0556.

Weyl OLF, Ellender BR, Woodford DJ, Jordaan MS. Fish distributions in the Rondegat River, Cape Floristic Region, South Africa, and the immediate impact of rotenone treatment in an invaded reach. African J Aquat Sci. 2013;38(2):201-9. https://doi.org/10.2989/16085914.2012 .753401 .

Whitmore DH. Introgressive hybridization of smallmouth bass (Micropterus dolomieui) and Guadalupe bass (M. treculi). Copeia. 1983; 1983(3):672-9. https://doi.org/10.2307/1444331.

Wisconsin SeaGrant. Threespine stickleback (Gasterosteus aculeatus). 2016. Accessed 12 Nov 2021.

Xu H, Qiang S, Genovesi P, Ding H, Wu J, Meng L, et al. An inventory of invasive alien species in China. NeoBiota. 2012;15:1-26. https:// doi.org/10.3897/neobiota.15.3575. 